\title{
ASSESSMENT OF WILD BOAR ROOTING ON ECOLOGICAL AND PASTORAL VALUES OF ALPINE PYRENEAN GRASSLANDS
}

\author{
C. G. BUENO ${ }^{1 *}$, I. C. BARRIO ${ }^{1,2}$, R. GARCÍA-GONZÁLEZ ${ }^{1}$, \\ C. L. Alados ${ }^{3} \&$ D. GÓMEZ-GARCía ${ }^{1}$ \\ 1 Pyrenean Institute of Ecology, Spanish National Research Council (CSIC), \\ Avda. Regmto. Galicia, s/n P. O. Box 64, Jaca 22700, Huesca, Spain \\ 2 Departament of Zoology, University of Córdoba, Campus de Rabanales, 14071, Córdoba, Spain \\ 3 Pyrenean Institute of Ecology, Spanish National Research Council (CSIC), \\ Avda. Montañana 1005, P. O. Box 13034, 50192 Zaragoza, Spain \\ ${ }^{*}$ Corresponding author: E-mail cgbuenog@gmail.com
}

\begin{abstract}
Wild boar rooting is nowadays one of the main disturbances in Pyrenean alpine grasslands. Its consequences for the ecosystem are not perfectly understood yet despite alpine grasslands in the Pyrenees have an important economic role and a priority conservation interest. The ecosystem services of this habitat lay mainly on pastoral and ecological values that wild boar rooting seems to affect. In this study, we measured those ecological and pastoral values at different scales to improve our understanding of the reach of these disturbances in this sensitive ecosystem. At landscape and community scales we compare disturbed and undisturbed areas in pastoral, ecological and community maps of the study area by means of a geographic information system. At a local scale we compare ecological and pastoral values of different plant groups (based on species abundance), within and outside wild boar rootings. A preference for areas of high pastoral and intermediate ecological values was found for wild boar rooting at the landscape level. However at the community level, disturbances notably reduced pastoral and ecological values in all communities. At the local level, the ecological value of bulbs and the pastoral value of annual dicots increased within disturbances, suggesting that disturbances may favour functional group diversity. In sum, wild boar rooting affects Pyrenean alpine grasslands moderately, with higher affection to pastoral than ecological values at all levels, what should be considered for the management and preservation of these habitats since these disturbances are likely to increase.
\end{abstract}

Keywords: Sus scrofa; disturbance assessment; multi-scale evaluation; Ordesa and Monte Perdido National Park. 
C. G. BUENO, I. C. BARRIO, R. GARCÍA-GONZÁLEZ, C. L. ALADOS \& D. GÓMEZ-GARCÍA

RESUMEN.- Las hozaduras de jabali son una de las mayores perturbaciones actuales de los pastos supraforestales pirenaicos. Sus consecuencias para el ecosistema no están todavía perfectamente descritas, a pesar de ser uno de los hábitats de mayor interés de conservación y que juegan un importante papel en las economías locales. Los bienes y servicios que provee dicho hábitat están claramente relacionados tanto con su valor ecológico como pastoral, los cuales parecen estar afectados por las citadas perturbaciones. En este trabajo se midieron dichos valores dentro y fuera de perturbaciones a diferentes escalas espaciales para incrementar el conocimiento de la repercusión de las hozaduras de jabali en el ecosistema de los pastos alpinos, particularmente sensibles a la remoción del suelo. A escala de paisaje y de comunidad, comparamos las áreas perturbadas y no perturbadas por el jabali, en mapas del valor pastoral, valor ecológico y de comunidades pascícolas de la zona de estudio, por medio de un sistema de información geográfica. A escala local comparamos los valores ecológico y pastoral de los grupos de plantas (sobre la base de la abundancia de especies), dentro y fuera de las hozaduras de jabali. A escala de paisaje se encontró una preferencia por zonas de alto valor pastoral y valores ecológicos intermedios. Sin embargo, a escala de comunidad las perturbaciones redujeron notablemente el valor pastoral y ecológico en todas las comunidades. A escala local, se encontró un aumento del valor ecológico de los bulbos y del valor pastoral de las dicotiledóneas anuales dentro de las perturbaciones, lo que sugiere que éstas pueden favorecer la diversidad de grupos funcionales. Las hozaduras de jabali afectan moderadamente a los pastos alpinos pirenaicos, con mayor afección sobre los valores pastorales que sobre los ecológicos en todas las escalas estudiadas, lo que debiera tenerse en cuenta para el manejo y preservación de estos hábitats, ya que dichas perturbaciones se están, muy probablemente, incrementando.

Palabras clave: Hozaduras de jabalí; evaluación de las perturbaciones; valor ecológico; valor pastoral; evaluación multi-escala; Parque Nacional de Ordesa y Monte Perdido.

\section{Introduction}

A crucial step to value an ecosystem is to accurately report how it may contribute to human wellbeing, through measuring what have been called 'ecosystem services'. This term includes both the naturally-occurring ecological processes and the benefits to humans that can be derived from them (Balmford et al., 2008). However, we still lack the theoretical basis that links ecological diversity to ecosystem services underlying human wellbeing (Carpenter et al., 2006). The need to develop indicators that synthesize and simplify the ecological complexity has been recently claimed, to aid monitoring biological, physical and social changes related to the ecosystem services (Carpenter et al., 2006). 
The main ecosystem services provided by mountainous areas are related to the provision of high quality water and food, control of climate and erosion, biodiversity and carbon storage, as well as recreation, aesthetic and spiritual values (Millennium Ecosystem Assessment Board, 2005). The greatest historical environmental change in these areas has been the spread of grasslands through scrubland and forest reduction from the Middle Ages on (Fillat et al., 2008). This progressive change due to livestock activities has developed a seminatural system with high ecological and pastoral values in a dynamic trade-off based on plant-herbivore interactions (Olff \& Ritchie, 1998; Austrheim \& Eriksson, 2001; Fillat et al., 2008). More recently, livestock grazers have changed in European mountain systems from almost exclusive sheep herds to comparatively higher numbers of cattle heads (Macdonald et al., 2000; Lasanta-Martínez et al., 2005). Alongside with this trend, a sharp decline of extensive husbandry has occurred in the last decades in favour of more productive intensive farming systems (Luick, 1998; Körner, 1999). In particular, this last trend has been related with drastic changes in the ecosystem structure, such as shrub encroachment and forest recolonization (Lasanta-Martínez et al., 2005; Lasanta-Martínez et al., 2006), what in turn may increase fire events (Carcaillet et al., 2009), reduce biodiversity (Helm et al., 2006), and boost some forest animal populations beyond an equilibrium threshold (Laiolo et al., 2004).

Wild boar is a native forest species whose populations have been increasing from the sixties in their European distribution range (Sáez-Royuela \& Tellería, 1986) being nowadays considered a pest in several areas within and outside its native distribution range (Oliver \& Leus, 2008). The main effect of its presence is an extensive disturbance that consists in turning over the soil while searching for underground feeding resources. These disturbances (hereafter 'rooting') affect directly some ecosystem elements, such as soils (Lacki \& Lancia, 1983; Bueno et al., unpublished-b) and vegetation (Bratton, 1975; Bueno et al., unpublished-a), and may indirectly alter some ecosystem processes such as nutrient cycling and species turnover (Kotanen, 1995; Bueno et al., unpublished-b). Rooting can be worrisome in some places, as it may affect habitats particularly sensitive to soil disturbances such as Pyrenean alpine grasslands (García-González, 2008) with indirect consequences to traditional grazing activities that preserve the system and hold local economies (Bueno et al., 2010). Therefore, evaluating the direct and main indirect implications of these disturbances is basic to guide adequate management actions and understand future consequences (Carpenter, 2002). Despite its relevance for conservation and management, little attention has been given to the evaluation of alpine grasslands ecologically and in terms of forage quality (Gartzia et al., 2005; García-González et al., 2007) and even less 
the approaches that take into account the main disturbances that affect such sensitive areas (García-González et al., 2003).

The main objective of the present study is to determine the effect of wild boar rooting in terms of pastoral and ecological values of Pyrenean alpine grasslands. We are especially interested in measuring its effect on ecological and pastoral attributes of grasslands at the landscape (1), the plant community (2) and plant functional group (3) levels within and outside wild boar disturbances. The integration of these three levels may provide insights into the global assessment of this animal impact to a sensitive ecosystem within a protected area such as Ordesa and Monte Perdido National Park (OMPNP).

\section{Methods}

\subsection{Study area}

The study was carried out in the alpine grasslands (above the present treeline; sensu Körner 1999) within Ordesa and Monte Perdido National Park (OMPNP; $42^{\circ} 36^{\prime} \mathrm{N}, 0^{\circ} 00^{\prime}$ ), located in the Spanish Central Pyrenees. The extent of the study area is 3.865 ha ( $25 \%$ of the entire National Park), ranging from 1500 to $2800 \mathrm{~m}$ a.s.l. The climate in this area is a proper high-mountain climate with $5^{\circ} \mathrm{C}$ and $1720 \mathrm{~mm}$ of annual average temperature and precipitation respectively (García-González et al., 2007). Lithology comprises mainly calcareous substrates such as limestone, sandstone and flysch (an overlaying complex of marlstone and sandstones). Pyrenean alpine communities within OMPNP can be structurally separated into sparse and dense grasslands depending on plant cover and soil depth (Bueno et al., 2009). For community comparisons, we selected the five most disturbed plant communities, with a total extent of 2309.4 ha, close to $2 / 3$ of the total surface, but receiving more than $96 \%$ of wild boar disturbances in the study area (Bueno et al., 2009). Plant communities were classified at alliance levels following phytosociological procedures (Braun-Blanquet, 1979; Benito, 2006). The selected communities are all dense grasslands located at sites with smooth topography and elevations lower than $2400 \mathrm{~m}$ a.s.l. Communities mainly differ in their diversitydominance composition of species and their livestock use. Three of them are dominated by one grass species: Festucion eskiae (FE), Festucion paniculatae (FP) and Nardion strictae (NS) by Festuca eskia, F. paniculata spadicea and Nardus stricta, respectively. The other communities have tree or more co-dominant species: Bromion erecti (BE; Festuca rubra nigrescens, Agrostis capillaris, Plantago media, etc) and Rumicion pseudoalpini (RP; Chenopodium bonus-henricus, Rumex 
alpinus, Poa supina, etc) (Fillat et al., 2008). Among these plant communities a grazing gradient can be set, from the most to the least used by livestock: RP $>\mathrm{BE}>\mathrm{FP}>\mathrm{NS}>\mathrm{FE}$ (Fillat et al., 2008). Grazing use and plant diversity are intrinsically linked especially in RP and BE. The occurrence of RP is totally dependent on the high presence of livestock and the extent of BE depends partly on moderate intensities of grazing (Fillat et al., 2008). Extensive husbandry is the main land use within OMPNP, mainly by cattle and sheep with little contribution of horses. Wild boar is relatively abundant in the surroundings of OMPNP with densities from 3.3 to 3.8 boars $/ \mathrm{km}^{2}$ (Herrero et al., 2005; Giménez-Anaya et al., 2010). It lives in the forest but visits alpine grasslands whenever forest feeding resources are scarce and soils are wet enough to be easily grubbed (Welander, 2000; HERRERO et al., 2005). Therefore wild boar disturbances occur mainly in late spring, with the snow-melting effect on soil, and early Autumn, with higher rainfall events (García-González et al., 2003). Also it has been suggested that protected areas where hunting activity is forbidden can act as refuges for wild boars (Acevedo et al., 2006; Herrero et al., 2006) so higher wild boar disturbances within OMPNP can be expected (Bueno et al., 2009).

\subsection{Wild boar rooting, ecological and pastoral maps}

Wild boar rooting in the study area was mapped during summer 2005 (June-August; for more details see Bueno et al., 2009). The whole study area was explored, and each disturbance patch over one squared meter was drawn over an aerial photograph (scale 1:3500). Most disturbance patches were also georeferenced by GPS (more than 1600 GPS data; Figure 1). Then the map was elaborated crossing both sources of information (drawings and GPS data) in a Geographic Information System (Bueno et al., 2009; Figure 1). The accuracy of the map was also evaluated taking 120 random points clearly falling within disturbance patches and 120 outside those patches (i.e. clearly outside disturbances) and calculating the overall accuracy of the map through a confusion matrix (Congalton \& Green, 2009). The overall accuracy of the map was $90.6 \%$ of correct classification (Bueno et al., 2010).

For the ecological and pastoral maps we used a previous vegetation map of the area of a similar scale (1:5000; García-González et al., 2007). The extent of each plant community was replaced by the ecological and pastoral values of each community previously calculated for the Spanish Central Pyrenees (García-González et al., 2007). Those values were categorized into three levels; low, medium and high, taking three equal intervals of the ecological and pastoral range values for the study area (Figure 1). 
a) Ecological Values

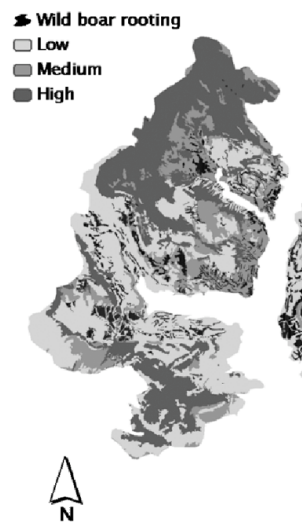

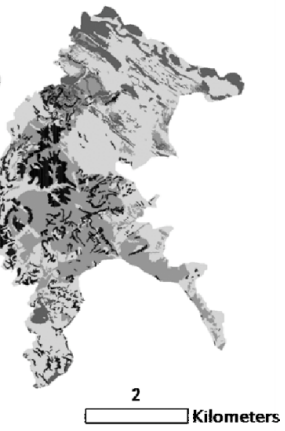

b) Pastoral Values

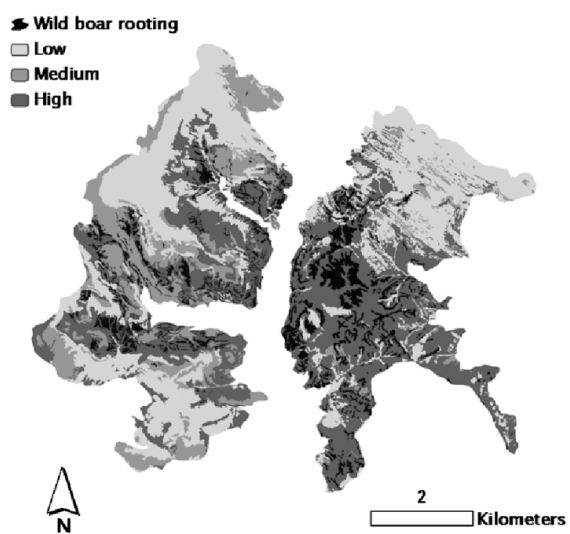

Figure 1. Wild boar rooting, ecological (a) and pastoral (b) values in the study area within OMPNP. Ecological and pastoral values were reclassified into 3 categories from three equal intervals of the ecological and pastoral range values of the study area.

Figura 1. Hozaduras de jabalí y valores ecológicos y pastorales en la zona de estudio dentro del PNOMP. Los valores ecológicos y pastorales fueron reclasificados en 3 categorías correspondientes a 3 intervalos equitativos del rango de valores ecológicos y pastorales de la zona de estudio.

\subsection{Sampling design and data collection}

To determine the composition of species, and their relative abundance, comparatively within and outside disturbances a paired stratified sampling design was used. 40 sampling units were randomly located within disturbance patches in each community. For each sampling unit within disturbances another sampling unit outside disturbances was set the closest possible to the previous (400 sampling units in total). Therefore the design was stratified by plant communities and paired within/outside disturbances. The sampling unit was composed by two square frames of $25 \times 25 \mathrm{~cm}, 5 \mathrm{~cm}$ grid. The size of the square frame was selected as a proxy of the minimum wild boar disturbance size (unit of disturbances) found in this habitat (CGB, pers.obs). In each square, 25 point-intercept contacts were set in the bottomleft corner of each grid (50 point-intercept contacts per sampling unit, 20,000 in total). To quantify the abundance of species, all individuals contacted by a vertical nail at each point-intercept were recorded (Goodall, 1952). Among the species found, we distinguished four types of functional groups: annual and perennial dicots, graminoids (most of them perennial in the study area), and bulbs. 


\subsection{Ecological and pastoral values for community and plant functional groups}

Community pastoral and ecological values were calculated as the average values obtained multiplying the frequency of the species for each sampling unit in each community within and outside disturbances (previously sampled, see data collection section) by the species ecological (EV) and pastoral values (PV; see below) previously calculated in this area (García-González et al., 2007). We refer as pastoral value to what García-González (2007) referred as potential pastoral value, without considering the selection of the herbivore.

Ecological and pastoral values of plant functional groups were obtained from calculating the total abundance of each species within and outside disturbances, separately. These abundance values were then multiplied by their corresponding values of EV and PV previously calculated. For each functional group, its percentage was calculated by adding up the values (EV and PV separately) for each species belonging to each functional group and divided by the total value of all species.

EV was estimated as the average of three ordinal components (values ranging from 0 to 5) related to plant species distribution in Europe, the Iberian Peninsula and the Spanish Pyrenees (Gómez-García et al., 2002).

PV was calculated by dividing the quality of each species by a proper conversion factor to get comparable values to ecological values (in our study the conversion factor was equal to ten). Quality of each species is obtained by summing up the percentages of total plant nitrogen $(\mathrm{N})$ and total plant phosphorous $(\mathrm{P})$, multiplied by its digestibility $(\mathrm{Dg})$, expressed as the percentage of dry matter; $\mathrm{Q}=(\mathrm{N}+\mathrm{P})$ x Dg (Gómez-García et al., 2002; García-González et al., 2007; Fillat et al., 2008). Pastoral values for community level in this study, differed from Gómez-García et al., (2002) in that they were calculated taking into account the quality values of the most abundant species and their frequencies within communities, instead of analyzing the quality and production from community samples per se.

\subsection{Statistical analyses}

To determine whether the occurrence wild boar rooting on the OMPNP grasslands was related to areas comprising low, medium or high ecological and pastoral values, we used resource selection analysis (RSA) (Manly et al., 1993). RSA compares the used area (disturbed by wild boar) to the available, where the null hypothesis is that wild boars root up the soil independently of its ecological and pastoral values, i.e. in proportion to their availability in the study area. RSA is based first on a Chi-squared Test, to test the null hypothe- 
sis and after rejection, Bonferroni confidence intervals are used to detect which level (low, medium or high) of ecological and pastoral values are (more or less) selected relative to their availability (Manly et al., 1993; Alldredge \& Griswold, 2006).

To assess the differences between disturbed and undisturbed plant communities in ecological and pastoral values, we used paired t-tests owing to the pair-matched sampling design (disturbed-undisturbed). Ecological values were square root transformed to achieve normality. All statistical analyses were performed with R 2.10.1 (R Development Core Team, 2010).

\section{Results}

At the landscape level, wild boar significantly selected areas with intermediate ecological values, avoiding those with high ecological values and used those with low ecological values in proportion to their availability (Figure 2a). On the contrary, areas with high pastoral values were actively selected by wild boar to root while low and intermediate values were significantly avoided (Figure $2 b$ ).

a) Ecological Value

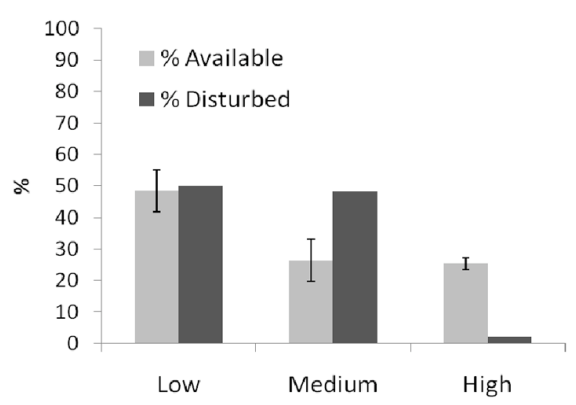

b) Pastoral Value

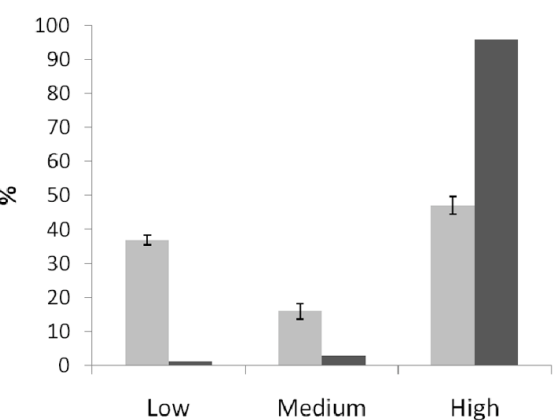

Figure 2. Percentage of disturbed areas by wild boar rooting in comparison to percentage of available grasslands at low, medium and high ecological (a) and pastoral (b) values. Error bars represent Bonferroni confident intervals (BCI). Percentage of disturbed areas higher or lower than BCI, means selection or avoidance of wild boar to root in each level respectively. All pairs of comparisons were significant at $\mathrm{p}<0.001$ except low ecological values that were not significant. Figura 2. Porcentaje de las zonas perturbadas por las hozaduras de jabali en comparación con el porcentaje de la superficie de pastos disponibles clasificados según su valor ecológico bajo, medio y alto (a) y según su valor pastoral bajo, medio y alto (b). Las barras de error representan intervalos de confianza de Bonferroni (BCI). Porcentajes de las zonas alteradas superiores o inferiores al $B C I$, significan preferencia o rechazo del jabali para hozar. Todos los pares de comparaciones fueron significativos $(p<0,001)$, excepto para los valores ecológicos bajos, que no fueron significativos. 
At the community scale, ecological values were higher in undisturbed areas than in disturbed ones when considering all plant communities together $(t=-16.02 ; p=0.000)$. This trend was consistent within each plant community (Figure 3a). In relation to the pastoral value, a similar trend was detected towards a decrease in pastoral value within disturbances for all communities taken together $(\mathrm{t}=-20.04 ; \mathrm{p}=0.000)$ and separately (Figure $3 \mathrm{~b})$.

a) Ecological value

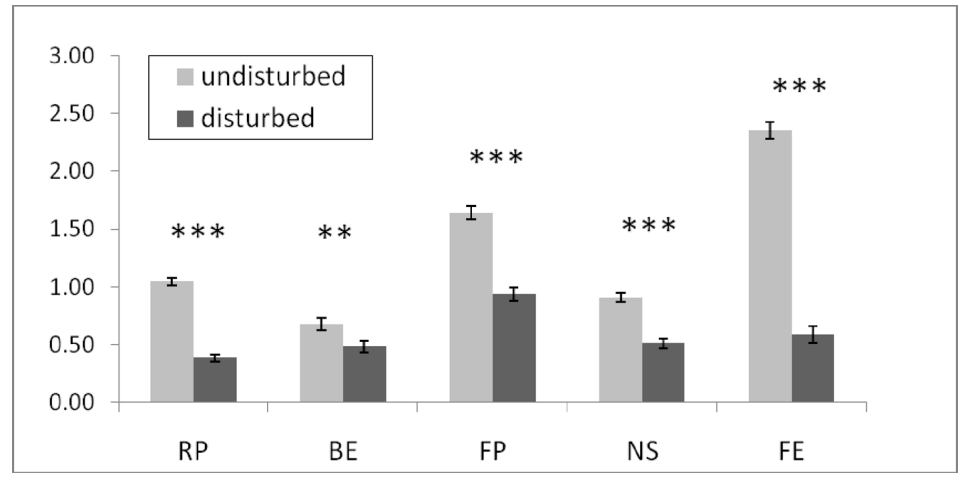

b) Pastoral value

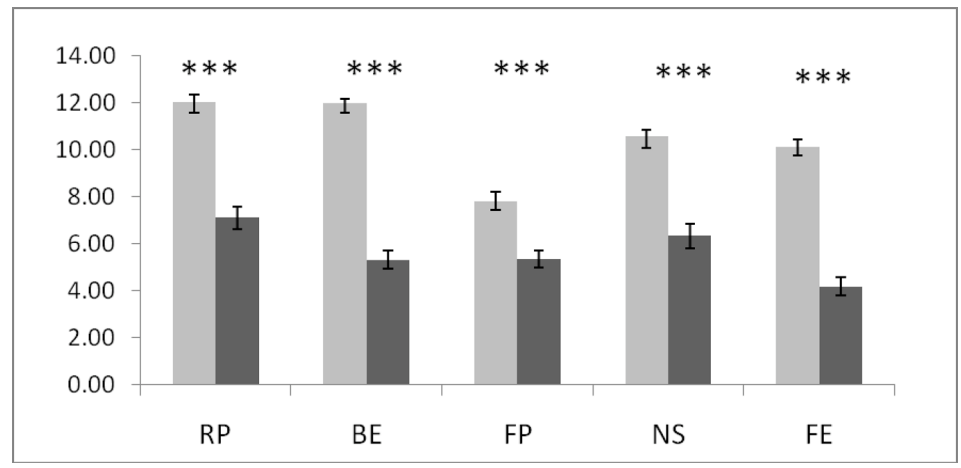

Figure 3. Ecological (a) and pastoral (b) values within and outside wild boar disturbances in the five grassland communities most affected by rooting. Mean values $( \pm \mathrm{SE})$ are shown. Significance of comparisons between disturbed and undisturbed areas within each plant community was assessed using paired t-tests and is indicated by the asterisks. ${ }^{* *} \mathrm{p}<0.01,{ }^{* * *} \mathrm{p}<0.001$. For community abbreviations see Methods.

Figura 3. Valores ecológicos (a) y pastorales (b) dentro y fuera de las perturbaciones de jabali en las cinco comunidades de pastos más afectadas por las hozaduras. Se muestran los valores medios \pm el error estándar. La significación de las comparaciones entre las zonas perturbadas y sin perturbar dentro de cada comunidad de pastos se evaluó mediante pruebas de la t-pareadas y se indica mediante asteriscos. ${ }^{* *} p<0,01,{ }^{* * *}$ $p<0,001$. Para las abreviaturas de la comunidad véase Métodos. 
For plant functional groups, both ecological and pastoral values outside disturbances were mainly due to graminoids and perennial dicots. Within disturbances the relative contribution changed, being perennial dicots the main group in determining both ecological and pastoral values. Interestingly, the ecological value of bulbs and the pastoral value of annual dicots increased within disturbances (Figure 4).

a) Ecological value

\section{Undisturbed Areas}

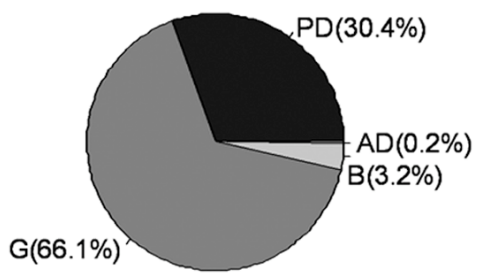

b) Pastoral value

\section{Undisturbed Areas}

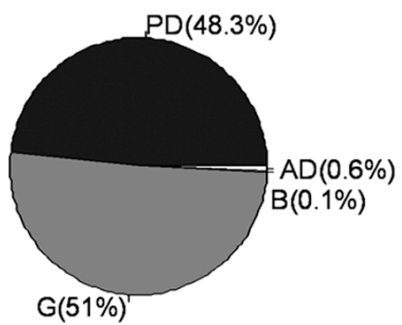

\section{Disturbed Areas}

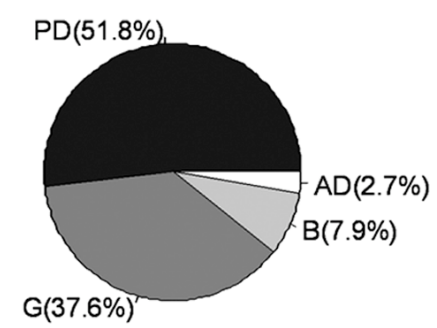

Figure 4. Distribution of ecological (a) and pastoral (b) values within and outside wild boar disturbances for plant functional groups. $\mathrm{PD}=$ perennial dicots, $\mathrm{G}=$ graminoids, $\mathrm{AD}=$ annual dicots, $\mathrm{B}=$ bulbs.

Figura 4. Distribución de los valores ecológicos (a) y pastorales totales (b) dentro y fuera de las hozaduras de jabalí por grupos funcionales de plantas. $P D=$ dicotiledóneas perennes, $G=$ graminoides, $A D=$ dicotiledóneas anuales, $B=$ bulbos. 


\section{Discussion}

The multi-scale approach used in the present study has let us assess the effects of wild boar rooting on ecological and pastoral values of Pyrenean alpine grasslands. At a landscape level, rooting affects mainly areas of high pastoral value, but it is least concerning from an ecological point of view. While searching for underground feeding resources rooting reduces plant cover at the community level, with the subsequent reduction in ecological and pastoral values. However, when detailed analyses are performed at the plant functional group level, responses differ within disturbances, even increasing the values for annual dicots and bulbs despite the reduction in plant cover.

At the landscape level, we found that wild boars select those areas that have a great pastoral value, which directly affect traditional grazing activities. Areas with higher pastoral values are those that are more used by livestock (García-González et al., 2007), hold the most nutrient-rich plants, and might be preferred by wild boars simply due to physiological constraints. Wild boars are monogastric animals, so that they cannot absorb nutrients from plant digestion as efficiently as do ruminants, which have a much longer and complex digestive system (Hofmann, 1989). Therefore, wild boars may need to look actively for high-nutrient content foods, which they would more easily find in these highly-valuable pastoral areas, as plants in highly grazed areas are suggested to have higher nutrient content, both above and belowground (Bryant et al., 1983; Gibson, 2009). However, this feeding selection for nutrient-rich food items may in part not fit previous results showing a preference of wild boars to root in livestock grazing areas that withstand a moderate stocking pressure instead of areas with high stocking pressure (Bueno et al., 2010). Assuming the most grazed areas i.e. areas with high stocking rate, have plants with higher nutrient content (Milchunas \& Laurenroth, 1993; Gibson, 2009), why would wild boars not prefer intensively-stocked instead of intermediate grazed areas? There are at least two plausible explanations for this. The first one relates to the physical properties of soils under high livestock pressure, since heavily grazed areas are more soil-compacted due to livestock trampling (Van Haveren, 1983; Albon et al., 2007; Bueno et al., unpublished-b), what would make it harder for wild boars to dig in them (Bueno et al., 2009). A second explanation would be that intensively-grazed plant communities are dominated by herbivore-tolerant species (Ritchie et al., 1998; Olofsson \& Oksanen, 2002). These plant species compensate the loss of biomass caused by herbivory through faster nutrient uptake rates that allow faster re-growth rates and the production of nutrient-rich tissues (Tilman, 1988; Holland et al., 1992). A key point here is where nutrient resources are 
allocated. In herbivore-tolerant species nutrient resources are mainly allocated aboveground, compensating for herbivory loss, while belowground biomass receives fewer nutrient resources (Holland \& Detling, 1990; Ritchie et al., 1998). This may explain why these areas dominated by herbivore-tolerant species are of less interest to rooting wild boars that instead display a grazing behaviour in these sites (C.G. Bueno pers. obs.). On the contrary, for intermediate grazed areas with moderate-to-low herbivore densities a decelerating effect on nutrient cycling can be expected (Tilman, 1988; Ritchie et al., 1998). In these cases herbivores may be more selective and feed on nutrient-rich plant species, subsequently increasing the dominance of nutrient-poor species or plants with physical or chemical defences against herbivory (Pastor \& Neiman, 1992; Ritchie et al., 1998; Hanley et al., 2007). These species may in turn have more resources belowground as they invest more in rooting competence (Tilman, 1988), being potentially more attractive to rooting wild boars.

On the other hand, wild boar rooting mainly affected areas with an intermediate ecological value. This might be related to the origin and dynamics of these grasslands in the Middle Ages, when lands were gained to the forest for grazing activities (Fillat et al., 2008; Bueno et al., 2010). The floristic composition of those communities might have changed from stress-tolerant species in the early stages, to grazing-tolerant species spread or even brought along from lowland areas by livestock (Austrheim et al., 1999). These species introduced by livestock have a very wide distribution being some of them sub-cosmopolitan, leading thus to plant communities with lower ecological values. Currently, species and communities with higher ecological value would be more restricted to rocky or high elevation habitats, where livestock does not graze (García-González et al., 2007; García \& Gómez-García, 2007) and wild boar does not root (Bueno et al., 2009).

Regarding the effect of rooting in the ecological and pastoral value of plant communities, a decreasing trend was detected for all plant communities. Lower ecological and pastoral values within disturbed areas can be simply explained by a sharp decrease in plant cover, which would reduce the potential pastoral biomass together with the occurrence of ruderal or fugitive species within disturbances (Kotanen, 1995; Bueno et al., unpublished-a). When studying plant functional groups in more detail, the trend is similar; graminoids, the main component of undisturbed grasslands, decrease, while perennial dicots and to a lesser extent bulbs and annual dicots, more related with the regenerative niches, notably increase their pastoral and ecological values within disturbances.

In conclusion, wild boar mainly affects to pastoral and, to a lesser extent, to ecological values of Pyrenean grasslands at the landscape and community level. For ecological values, despite finding a clear trend of ecological degra- 
dation due to disturbances, areas of high ecological value remained unaffected. Therefore, notwithstanding the vast extent of wild boar rooting (321.5 ha in the study area; Bueno et al., 2009) and the evident affection to grazing in this protected area $(16.2 \%$ of livestock grazing area affected by wild boar rooting; Bueno et al., 2010), the impact of wild boar may be considered as moderate in terms of current conservation value. Nevertheless, the potentially increasing trend of this disturbance (Bueno et al., 2010) may lead to some concerns regarding the preservation of these habitats in the near future.

\section{Acknowledgements}

We would like to thank María Bueno, Ricardo Pineda and Dorleta Jiménez for field assistance, Maite Gartzia for digitalizing and ground-truthing vegetation maps and the staff of Ordesa and Monte Perdido National Park for the support and data provided. CGB was funded by a FPU fellowship from the Spanish Ministry of Education. Additional comments provided by two anonymous reviewers greatly improved earlier versions of this manuscript. We gratefully acknowledge the support of the Spanish Science and Innovation Ministry (PN-MCI) (CGL2008-00655/BOS), the Spanish Environmental Ministry, and the National Parks Network (MMAMRM 002/2007).

\section{References}

Acevedo, P., Escudero, M.A., Múñoz, R. \& Gortázar, C., 2006. Factors affecting wild boar abundance across an environmental gradient in Spain. Acta Theriologica, 51: 327-336.

Albon, S.D., Brewer, M.J., O’brien, S., Nolan, A.J. \& Cope, D., 2007. Quantifying the grazing impacts associated with different herbivores on rangelands. Journal of Applied Ecology, 44: 1176-1187.

Alldredge, J.R. \& Griswold, J., 2006. Design and analysis of resource selection studies for categorical resource variables. The Journal of Wildlife Management, 70: 337-345.

Austrheim, G. \& Eriksson, O., 2001. Plant species diversity and grazing in the Scandinavian mountains-patterns and processes at different spatial scales. Ecography, 24: 683-695.

Austrheim, G., Gunilla, E., Olsson, A. \& Grøntvedt, E., 1999. Land-use impact on plant communities in semi-natural sub-alpine grasslands of Budalen, central Norway. Biological Conservation, 87: 369-379. 
Balmford, A., Rodrigues, A., Walpole, M., Ten Brink, P., Kettunen, M., Braat, L. \& Groot, R., 2008. Review on the economics of biodiversity loss: scoping the science. European Commission, Cambridge.

Benito, J.L., 2006. Vegetación del Parque Nacional de Ordesa y Monte Perdido (Sobrarbe, Pirineo central aragonés). Publicaciones del Consejo de Protección de la Naturaleza de Aragón, 421 pp., Zaragoza.

Bratton, S.P., 1975. The effect of the European wild boar, Sus scrofa, on Gray Beech Forest in the Great Smoky Mountains. Ecology, 56: 1356-1366.

Braun-Blanquet, J., 1979. Fitosociología, bases para el estudio de las comunidades vegetales. Blume Ediciones, 820 pp. Madrid.

Bryant, J.P., Chapin, F.S. \& Klein, D.R., 1983. Carbon/nutrient balance of boreal plants in relation to vertebrate herbivory. Oikos, 40: 357-368.

Bueno, C.G., Alados, C.L., Gómez-García, D. \& Barrio, I.C., unpublished-a. Effects of wild boar rooting on plant diversity, composition and spatial variation in Pyrenean alpine grasslands.

Bueno, C.G.; Alados, C.L., Gómez-García, D., Barrio, I.C. \& García-González, R., 2009. Understanding the main factors in the extent and distribution of wild boar rooting on alpine grasslands. Journal of Zoology, 279: 195-202.

Bueno, C.G., Azorín, J., Gómez-García, D., Alados, C.L. \& Badía, D., unpublished-b. Soil responses to large wild boar disturbances in Pyrenean alpine grasslands.

Bueno, C.G., Barrio, I.C., García-González, R., Alados, C.L. \& Gómez-García, D., 2010. Is wild boar rooting affecting livestock grazing in alpine grasslands? European Journal of Wildlife Management, 56: 765-770.

Carcaillet, C., Ali, A.A., Blarquez, O., Genries, A.L., Mourier, B. \& Bremond, L., 2009. Spatial Variability of Fire History in Subalpine Forests: From Natural to Cultural Regimes. Ecoscience, 16: 1-12.

Carpenter, S.R., 2002. Ecological futures: building an ecology on the long now. Ecology, 83: 2069-2083.

Carpenter, S.R., Defries, R., Dietz, T., Mooney, H.A., Polasky, S. \& Reid, W.V. \& Scholes, R.J., 2006. Millennium Ecosystem Assessment: Research Needs. Science, 314: 257-258.

Congalton, R.G. \& Green, K., 2009. Assesing the accuracy of remotely sensed data: principles and practices. CRC Press, BocaRaton.

Fillat, F., García-González, R., Gómez, D. \& Reiné, R., 2008. Pastos del Pirineo. CSIC - Diputación de Huesca, 319 pp., Madrid.

García-González, R., 2008. Management of Natura 2000 habitats. 6170 Alpine and subalpine calcareous grasslands. In: European Commission (Ed.), Technical Report 2008 11/24, 23 pp. http://ec.europa.eu/environment/ nature/ natura2000/ management/habitats/models_en.htm. 
García-González, R., Alados, C.L., Bueno, G., Fillat, F., Gartzia, M., Gómez, D., Komac, B., Marinas, A. \& Saint-Jean, N., 2007. Valoración ecológica y productiva de los pastos supraforestales en el Parque Nacional de Ordesa y Monte Perdido In: Ramirez, L. \& Asensio, B. (Eds.), Proyectos de investigación en Parques Nacionales: 2003-2006. pp. 105-128, OAPN-MMA, Madrid.

García González, R., Marinas Murillo, A. \& Sanz, G., 2003. Valoración del impacto de las hozaduras del jabali en los pastos supraforestales del Parc National des Pyrénées. Unpublished report, pp. 86. Parc National des Pyrénées Instituto Pirenaico de Ecología, Jaca.

García, M.B. \& Gómez-García, D., 2007. Flora del Pirineo aragonés, patrones espaciales de biodiversidad y su relevancia para la conservación. Pirineos, 162: 71-88.

Gartzia, M., Marinas, A., Campo, A. \& Gómez-García, D., 2005. Valoración eco-pastoral de los pastos supraforestales de Aísa (Pirineo Occidental). In: De la Roza, B. et al. (eds.), Producciones agroganaderas: Gestión eficiente y conservación del medio natural. SERIDA, pp. 817-824, Gijón

Gibson, D.J., 2009. Grasses and grassland ecology. Oxford University Press, 305 pp., Oxford.

Giménez-Anaya, A., Herrero, J., García-Serrano, A., Prada, C. \& GarcíaGonzález, R., 2010. Long-term wild boar monitoring in the Pyrenees reveals a positive trend. 8th International Symposium on wild boar and other suids, York, UK, p. 83.

Gómez-García, D.; GARCÍA-GONZÁLEZ, R.; MARINAS, A. \& ALDEZABAL, A., 2002. An eco-pastoral index for evaluating Pyrenean mountain grasslands. In: Durand, J.L., Emile, J.C., Huyghe, C., Lemaire, G. (Eds.), Multi-Function Grasslands. Quality Forages, Animal Products and Landscape. Association Française Production Fourragère, pp. 922-923, Poitiers, France.

Goodall, D.W., 1952. Some considerations in the use of point quadrats for the analysis of vegetation. Aust. J. Sci. Res. Bull., 5: 1-41.

Hanley, M.E., Lamont, B.B., Fairbanks, M.M. \& Rafferty, C.M., 2007. Plant structural traits and their role in anti-herbivore defence. Perspectives in Plant Ecology, Evolution and Systematics, 8: 157-178.

Helm, A., Hanski, I. \& Pärtel, M., 2006. Slow response of plant species richness to habitat loss and fragmentation. Ecology Letters, 9: 72-77.

Herrero, J., Irizar, I.; Laskurain, N.A., García-Serrano, A. \& García González, R., 2005. Fruits and roots: wild boar foods during the cold season in the southwestern Pyrenees. Italian Journal of Zoology, 72: 49-52. 
Herrero, J., Prada, C., García-Serrano, A. \& Fernández Arberas, O., 2006. Mamíferos de Guara. Publicaciones del Consejo de Protección de la Naturaleza de Aragón, 165 pp., Zaragoza.

Hofmann, R.R., 1989. Evolutionary steps of ecophysiological adaptation and diversification of ruminants: a comparative view of their digestive system. Oecologia, 78: 443-457.

Holland, E.A. \& Detling, J.K., 1990. Plant Response to Herbivory and Belowground Nitrogen Cycling. Ecology, 71: 1040-1049.

Holland, E.A., Parton, W.J., Detling, J.K. \& Coppock, D.L., 1992. Physiological responses of plant populations to herbivory and their consequences for ecosystem nutrient flow. The American Naturalist, 140: 685-706.

Körner, C., 1999. Alpine plant life. Functional plant ecology of high mountain ecosystems. Springer-Verlag: 338 pp., Berlin.

Kotanen, P.M., 1995. Responses of vegetation to changing regime of disturbance: effects of feral pigs in a Californian coastal prairie. Ecography, 18: 190-199.

Lacki, M.J., Lancia, R.A., 1983. Changes in soil properties of forests rooted by wild boar. Proc. Annu. Conf. Southeasth. Assoc. Fish and Wildl. Agencies 37, 228-236.

Laiolo, P., Dondero, F., Ciliento, E. \& Rolando, A., 2004. Consequences of pastoral abandonment for the structure and diversity of the alpine avifauna. Journal of Applied Ecology, 41: 294-304.

Lasanta-Martínez, T., González-Hidalgo, J.C., Vicente-Serrano, S.M. \& Sferi, E., 2006. Using landscape ecology to evaluate an alternative management scenario in abandoned Mediterranean areas. Landscape ad Urban Planning, 78: 101-114.

Lasanta-Martínez, T., Vicente-Serrano, S.M. \& Cuadrat-Prats, J.M., 2005. Mountain Mediterranean landscape evolution caused by the abandonment of traditional primary activities: a study of the Spanish Central Pyrenees. Applied Geography, 25: 47-65.

Luick, R., 1998. Ecological and socio-economic implications of livestock-keeping systems on extensive grasslands in south-western Germany. Journal of Applied Ecology, 35: 979.

Macdonald, D., Crabtree, J.R., Wiesinger, G., Dax, T., Stamou, N., Fleury, P., Gutiérrez-Lazpita, J. \& Gibon, A., 2000. Agricultural abandonment in mountain areas of Europe: Environmental consequences and policy response. Journal of Environmental Management, 59: 47-69.

Manly, B.F.J., Mcdonald, L.L., Thomas, D.L., Mcdonald, T.L. \& Erikson, W.P., 1993. Resource selection by animals: statistical design and analysis for field studies. Kluwer Academic Publishers: 236 pp., New York. 
Milchunas, D.G. \& Laurenroth, W.K., 1993. Quantitive effects of grazing on vegetation and soils over a global range of environments. Ecological Monographs, 63: 327-266.

Millennium Ecosystem Assessment Board, 2005. Living Beyond Our Means: Natural Assets and Human Well-Being, Statements from the board. www.millenniumassessment.org/proxy/document.429.aspx. Accessed on 2nd February 2006. United Nation Fundation.

Moore, D.S., Mccabe, G.P., Craig, B., 2008. Introduction to the practice of statistics. W.H Freeman. 100 pp., New York.

Olff, H. \& Ritchie, M.E., 1998. Effects of herbivores on grassland plant diversity. TREE, 13: 261-265.

Oliver, W. \& Leus, K., 2008. Sus scrofa. IUCN 2010. IUCN Red List of Threatened Species. Version 2010.3. <www.iucnredlist.org>

Olofsson, J. \& Oksanen, L., 2002. Role of litter decomposition for the increased primary production in areas heavily grazed by reindeer: a litterbag experiment. Oikos, 96: 507-515.

Pastor, J. \& Neiman, R.J., 1992. Selective foraging and ecosystem processes in boreal forest. The American Naturalist, 139: 690-705.

R Development Core Team, 2010. R: A language and environment for statistical computing. R Foundation for Statistical ComputingVienna, Austria. ISBN 3-900051-07-0, URL http: / / www.R-project.org.

Ritchie, M.E., Tilman, D. \& Knops, J.M.H., 1998. Herbivore effects on plant nitrogen dynamics in Oak Savanna. Ecology, 79: 165-177.

Sáez-Royuela, C. \& Tellería, J.L., 1986. The increased population of Wild Boar (Sus scrofa) in Europe. Mammal Review, 16: 97-101.

Tilman, D., 1988. Plant strategies and the dynamics and structure of plant communties. Princeton University Press, Princeton, New Jersey, USA.

Van Haveren, B.P., 1983. Soil Bulk Density as Influenced by Grazing Intensity and Soil Type on a Shortgrass Prairie Site. Journal of Range Management, 36: 586-588.

Welander, J., 2000. Spatial and temporal dynamics of a disturbance regime: wild boar (Sus scrofa) rooting and its effects on plant species diversity. PhD Thesis, Swedish University of Agricultural SciencesUtgivningsort, Sweden. 